\title{
Questions: An Essay in Daubertian Phenomenology
}

\author{
KARL SCHUHMANN \\ University of Utrecht \\ and \\ BARRY SMITH ${ }^{1}$ \\ University of Manchester
}

\section{$\S 1$. Introduction}

\subsection{What is a Question?}

A number of logicians and philosophers have turned their attention in recent years to the problem of developing a logic of interrogatives. Their work has thrown a great deal of light on the formal properties of questions and question-sentences and has led also to interesting innovations in our understanding of the structures of performatives in general and, for example, in the theory of presuppositions. When, however, we examine the attempts of logicians such as Belnap or Åqvist to specify what, precisely, a question is, or what it is to ask or raise a question, then what we are offered is somewhat less illuminating. Two alternative reductionist accounts seem in particular to have gained most favor: questions are identified either as special sorts of statements, ${ }^{2}$ or as special sorts of

1 Thanks are due to the Alexander von Humboldt-Stiftung for the award to Smith of a grant for research in Erlangen, where his contributions to this paper were written. Thanks are due also to the Philosophical Seminar of the University of Mannheim, where an earlier version of the paper was presented by Schuhmann.

2 See, e.g., Harrah: “'Whether' questions are identified with true exclusive disjunctions, whose disjuncts are the answers. 'Which-individuals' questions are identified with true existential quantifications; an answer to such a question states that the quantified function is satisfied by, and only by, a certain set of individuals" (1961, 40). G. Stahl (1969) goes so far as to consider questions as "classes of sufficient answers." 
requests. ${ }^{3}$ As we hope will become clear in what follows, neither of these accounts is even nearly adequate; and matters are not improved if questions are identified, by force majeure, as combinations of statements and requests. ${ }^{4}$

Of course, the purposes of the logician are such that it may not matter that his work is constructed on the basis of only partially adequate accounts of the phenomena he treats: logically valuable results may be achieved precisely by ignoring otherwise important distinctions. The problem of the nature of questions does, however, have an interest and an importance of its own. Moreover, there is a history of attempts to tackle this problem and from the examination of these attempts much profit can he gained. The present paper will concentrate above all on the writings of the early phenomenologists, and especially on the work of Husserl and Johannes Daubert on the nature of questions. This is first of all because it is in these writings that there are to be found the most detailed and successful accounts of phenomena of the given sort. But it is also because Daubert, in particular, bases his own account on a critical survey of the most important conceptions of such phenomena in the philosophical tradition. The examination of his views will thereby impose upon our deliberations a valuable historical perspective.

\subsection{Husserl on Meaning and Representation}

One of Husserl's best known theses is that of the intentionality of consciousness. All conscious acts refer, in one way or another, to an object. Some acts, above all judgments and acts of outer and inner perception, refer to their objects directly, and in the fifth of his Logical Investigations Husserl calls such acts 'objectifying acts' or 'representations' [Repräsentationen]. Other acts - for example feelings, desires, acts of will - have a merely indirect intentionality. They, too, however, are possible only insofar as they are founded upon acts of the representing sort, which supply them with their objects.

Objectifying acts are themselves of two sorts. On the one hand are pos-

3 Consider, e.g., Searle's remark: "asking questions is really a special case of requesting, viz., requesting information (real question) or requesting that the hearer display knowledge (exam question)." $(1969,69)$ Or Åqvist: One can handle the question "Which is the smallest prime greater than 500?" "by taking it to be short for the following somewhat tedious formulation: 'Act in such a way in the immediate future that, by your act (of answering), you cause that it will be the case that there is an object of which I know that it is the smallest prime greater than 500!'” (1975, IV, emphases removed.)

4 Thus Belnap and Steel: "An elementary question has two parts, a subject and a request. The subject presents a set of alternatives, and the request identifies how many of the true alternatives are desired in the answer and what sort of claims for completeness and distinctness are to be made." (1976, 3f.) 
iting acts which are accompanied by a moment of belief in the existence of their object (by what Frege called 'assertive force'). On the other hand are 'mere' representations, where such belief is lacking. Thus one can see a tree, but one can also imagine a tree. Now non-objectifying acts, Husserl argues, are not subject to a modification of this kind. They are, he insists, indifferent to the changes in 'position' [Setzung] which objectifying acts undergo in relation to their objects.

At first glance this view might seem misguided. Consider, for example, that non-objectifying act which is an act of wishing. Can one not merely wish but also imagine wishing, and does not this difference consist precisely in the presence or absence of belief? Not, Husserl insists, when we have recognized that "the mere imagining of a wish is the counterpart not of the wish, but of some positing act - e.g., a perception - directed to it"; it is the result of cancelling the belief-moment in some objectifying act of introspection (A453f./645). ${ }^{5}$

The general thesis of intentionality, then, asserts more precisely that non-objectifying acts must of necessity be accompanied by objectifying acts as their foundations, and that the latter must be either positing or non-positing. In addition to this general thesis, however, there is in Husserl also a special thesis relating specifically to the meaning or intentionality of uses of language. In fact Husserl's theory of linguistic meaning is an act-based theory of meaning that is grafted whole upon his theory of objectifying acts. It sees uses of language as having meaning not in themselves but only to the extent that they acquire meaning through associated acts. But more: all such acts must be objectifying, must have a direct relation to an object. Indeed the meaning of a linguistic expression, for Husserl, is just the manner in which, in using the expression, we are directed towards its object:

In meaning there is constituted a relation to the object. To use an expression significantly, and to refer expressively to an object (to form a presentation of it), are thus one and the same. It makes no difference whether the object exists or is fictitious or even impossible. (A54/293)

Meaning acts are then divided by Husserl into two broad classes: presentations [Vorstellungen], acts directed towards objects in the narrower sense (associated particularly with uses of names), and judgments, acts directed towards states of affairs (associated particularly with uses of sentences).

5 References in this form are to volume II of the first edition of the Logische Untersuchungen and to Findlay's English translation of the second edition, respectively. 
The most important consequence of Husserl's theory is that descriptive uses of language come to play a quite peculiarly privileged role, to the extent that Husserl is forced to conceive all apparently non-descriptive varieties of language-use as disguised cases of descriptive ones. Language can be meaningfully used in issuing commands or requests, for example, only because such uses are in each case bound up with acts which are of something in the direct, representational sense; and then it is these latter acts, not associated (non-objectifying) acts of will or states of desire, which give meaning to the corresponding utterances.

It is only in the very last chapter of the Logical Investigations that Husserl explicitly opposes non-objectifying acts to the objectifying ones which, as he sees things, are presupposed in all (uses of) wish- and command-sentences, and the main example which he uses for elucidating the structures thereby involved is the example of the question. ${ }^{6}$

Judgment-sentences and question-sentences do not belong to the same species of utterance, Husserl now tells us, because the ways in which they relate to the acts which provide them with their meanings are entirely different. The judgment-sentence expresses an act of judging; it is the judging that gives the sentence its meaning, and a judging is just a specific sort of representation of a state of affairs accompanied by a moment of belief. ${ }^{7}$

In the case of the question-sentence, however, things are different. Certainly, when we ask a question there is an act of questioning involved. But the question-sentence cannot be said to express (get its meaning from) this act, since the latter does not objectify. An act of questioning does contain objectifying elements, and is thereby related to one or more objects. But this act as a whole does not of itself say anything about these objects; it is not directly related to any Sachverhalt of its own in which these objects would be involved.

How, then, according to Husserl, does a use of language in asking a question get its meaning? Effectively via a turning inward: a question-sentence expresses not a questioning act but rather an inner perception in which such a questioning act is itself registered, and thereby given as object. A question-sentence thus contains an essential relation to "the inner experience of the one who speaks" (A690/848). ${ }^{8}$ It is but a corollary

6 In phenomenological circles the problem of the question has since been dealt with also by Stern (1924), Ingarden (1925) and inter alia by Fales, Pöltner, Coreth, Bergler, Rombach and Struyker Boudier.

7 Thus in the assertive use of a sentence it is the relevant state of affairs that is given as objectual correlate, not the act itself: "the judging or predicating is not itself objective" (A691/849)

8 There is a parallel to this doctrine in the Elémens d'idéologie of Destutt de Tracy (Part 2, p. 52): “'Avez-vous fini? Etes-vous prêt?' veulent dire je vous demande je desire savoir si, etc. Ce sont autant de jugemens portés sur moi-même que je vous exprime." See also 
of this that, according to Husserl, the communicative function of the question, no matter how important it may be in practical life, belongs to the merely "accidental specifications of utterances" (A692/850). For a question to be a question it does not matter whether it is directed to someone else or not. Husserl frankly concedes that this account is "reconcilable only with difficulty with other phenomenological facts" (A682/842). Yet one has to avow that it is fully consonant with his treatment of language in the Logical Investigations, for Husserl stresses from the very start the derivative status of those utterances which function "in living communication". All expressions, he insists, "display their meaning function even in the solitary life of the soul," and it is crucial to Husserl's entire approach to linguistic meaning that it should cope precisely with those features of meaningful uses of language which are present already in silent speech. ${ }^{9}$

\subsection{Husserl and Daubert}

It is only relatively recently that philosophers, both within and without the phenomenological tradition, have once more begun to read, and understand, the Logical Investigations. Already in 1902, however, the crucial importance of the work was recognized by Johannes Daubert, then a student of the philosopher and psychologist Theodor Lipps in Munich. Indeed it was Daubert, according to the testimony of one of his friends, who "contributed more than anyone else to making known the Logical Investigations," ${ }^{10}$ and it can be said without exaggeration that, by introducing Husserl's work in Munich and propagating it for more than a decade among his fellow students, Daubert in fact became one of the founders of the phenomenological movement. ${ }^{11}$

The enthusiastic support which was lent by Daubert to the Logical Investigations and to the frame of thought embodied in it did not however prevent him from criticizing Husserl whenever he found the latter's views to be inadequate, and one major issue on which Daubert diverged from the standpoint of the master was precisely in regard to the treatment of commands, wishes, questions and other performative uses of language. ${ }^{12}$

Karttunen 1977.

9 A24/269. Husserl refers to the "solitary life of the soul" also when treating of the question in Investigation VI (A690/848).

${ }^{10}$ Geiger, 1933, p. 4.

${ }^{11}$ Daubert remained a leading figure in the Munich circle until the outbreak of World War I. On Daubert and Munich phenomenology in general see Spiegelberg 1982, 169f. On Daubert's life see Schuhmann 1985, and Schuhmann and Smith 1985.

${ }^{12}$ For a preliminary survey of Daubert's criticisms of the Investigations see Smid 1985. These criticisms stand out not least because of the fact that Husserl himself took seriously 
For where, as we have seen, Husserl had treated such phenomena as derivative, assigning them to a level where they would depend upon a more fundamental layer of objectifying acts, Daubert maintained from the start that they call for special non-objectifying acts which would serve to provide them with their meanings in just the same non-roundabout way that, e.g., objectifying acts directed towards states of affairs provide the meanings of acts of judgments. He maintained, in other words, that expressed commands and wishes are phenomena collateral with statements or assertions, not disguised variations on the latter. But this meant giving up the strong Husserlian thesis according to which meaning is just the "manner of being directed to an object."

Daubert's concern with the meanings of performatives triggered off a series of investigations of the topic of non-objectifying acts by other members of the Munich circle, eventually culminating in the detailed and comprehensive theory of the act of promising which was published by Adolf Reinach in the first volume of Husserl's Jahrbuch. ${ }^{13}$

This Jahrbuch für Philosophie und phänomenologische Forschung, to give it its full title, was a joint undertaking sponsored by Husserl and the Munich group, and Daubert took a major part in the preparations for its launching. Like the other prospective co-editors - Reinach, Pfänder, Geiger, and Scheler (representing Munich), and Husserl (representing the rest of the world) - Daubert, too, was expected to contribute a major work to the first volume of the series. ${ }^{14} \mathrm{He}$ had been working since March 1911 on a "phenomenology of the question" and had accordingly planned to submit a piece on this topic..$^{15}$ And while he failed, as on earlier occasions, to produce a final version of his ideas in a publishable form, the drafts of his work have survived and have been collected in a convolute consisting of 87 full folio shorthand pages now deposited, along with Daubert's other posthumous papers, in the Bavarian State Library in Munich. ${ }^{16}$ It is this convolute which will form the nucleus of

what Daubert had to say, and Husserl's reactions are in many cases recorded in Daubert's manuscripts.

${ }^{13}$ Reinach was a member of the Munich group under Daubert's particular influence. His theory is discussed in detail in Smith 1985 and 1985a and now also in Burkhardt 1986.

${ }_{14}$ Daubert was in the end the only one to drop out.

${ }^{15}$ On the fate of Daubert's proposed contribution see Schuhmann 1987.

${ }_{16}$ The convolute, which carries the sigil Daubertiana A I 2, bears the title "Frage." The fact that Daubert's work is unknown even to specialists in phenomenology rests first of all on the fact that, during his lifetime, he published not a single word. His manuscript remains - see the survey in Avé-Lallemant 1975, 125-38 - were in addition written in an almost undecipherable shorthand. The manuscript A I 2 was transcribed in 1981 by Dr. Reinhold Smid as part of a research project sponsored by the University of Utrecht and supervised by Schuhmann. Smid's transcription is accessible in the Handschriftenab- 
the present paper.

\subsection{Daubert's Phenomenology of the Question}

The pages of Daubert's manuscripts are distinguished above all by their dense population of lists of differences among phenomena which, on the basis of superficial reflection, one might be disposed to identify. He begins his analysis of the question by distinguishing:

(a) the mental act of questioning (das Fragen),

(b) the question itself, as logical formation (die Frage),

and

(c) the question as addressed to someone, the directed question (die Anfrage).

This three-fold distinction then gives rise to the three main stages in his analysis. A treatment of (a) is necessary in order to "set apart the act of questioning from other experiences" (1r). ${ }^{17}$ This first stage represents the pars destruens of the whole project, since the act of questioning is all too often confounded with mental acts of other kinds. As already mentioned, Daubert sets out with comprehensive criticisms of the views on questions held by previous authors and the outlines of these criticisms have been incorporated in what follows. In a second stage Daubert develops his own "positive phenomenology" of the "question as logical formation" in the sense of (b) (29r, 31r, 42r). Here he examines, among other things, the relationship between question, judgment and state of affairs. In the third and final stage he considers the total field, linguistic as well as non-linguistic, which typically surrounds the asking of a question. Here he deals with a question's roots in the individual's interests, and with the role played by other persons in the execution of a question, i.e., as subjects to whom the question is addressed. And finally he deals also with the phenomenon of emphasis and with the relation of question and knowledge.

Our own exposition will follow Daubert in these three successive stages. We begin with Daubert's criticisms of traditional - reductionist - views of the questioning act and of the psychological underpinnings of interrogative phenomena in general.

teilung of the Bavarian State Library and at the Center for Advanced Research in Phenomenology in Pittsburgh (Pennsylvania) and Waterloo (Ontario).

${ }^{17}$ Quotations from Daubertiana A I 2 will be given by referring to page numbers with recto/ verso markings; these have been recorded also in the margins of the transcription. 


\section{§2. The Nature of the Questioning Act}

\subsection{Questioning Act vs. State of Uncertainty}

Perhaps the most common traditional interpretation of the questioning act, an interpretation which has prevailed since Boethius' De Topicis Differentiis, is that which talks in terms of doubts or of "feelings of uncertainty." Thus in the 19th century the logician Christoph Sigwart, to take just one example, declared a question to be a state of mind of which "doubt, presumption and expectation are but certain variations" (1904, 154). Such conceptions are dismissed by Daubert as completely mistaken. As he points out:

There exist presumptive questions as well as presumptive judgments: "A did this, I presume? — This was presumably done by A." Doubt can be implied in a question: "Is this P or Q?" as well as in a disjunctive judgment: "Either it's P, or it's Q." The content of a presumption and a doubt can enter into a question as well as into a judgment. (20r)

Such conceptions fail also to recognize the radical difference of temporal structure as between doubt and presumption on the one hand - which are enduring states - and the acts of judging and questioning on the other - which are occurrent episodes. Of course the confusion of the two is not entirely unmotivated, since the former typically serve as foundation for the latter (a parallel confusion is often present in contemporary analytic philosophers' talk of "propositional attitudes"). ${ }^{18}$ The confusion is present also in Benno Erdmann's account of questions as "predicative formulations of an uncertainty of thinking that is unsatisfied and in search of an answer" $(1907,391)$. Here, too, Daubert insists that uncertainty is a state. Further, it is a state that can perfectly well remain as it is without ever being transformed into its opposite, the state of certainty $(24 \mathrm{v})$.

\subsection{Questioning Act vs. Desire}

A second traditional view of the act of questioning his identified this act with one or other form of desiring, striving, etc., and it is certainly true that in questioning we aim at something - most usually at the acquisition of some specific type of knowledge. It is this character of purposiveness which led Meinong to assert that questions should be relegated "without further ado to the domain of appetites [Begehrungen] . . . Whoever asks a question thereby wants, after all, to receive an answer." ${ }^{19}$

${ }^{18}$ On the wider phenomenological importance of the distinction between acts and states see Mulligan and Smith 1986.

19 1910, 120; See also Åqvist, IX. Meinong's account is a reformulation of Cicero's definition: "Quaestio est appetitio cognitionis" (Academica Priora II, VIII, 26). 
Bolzano, too, conceived questions as "statements which utter the presence of a certain desire or wish." ${ }^{20}$ To this Daubert objects that desirings are in every case directed toward "the acquisition or possession of something that is of value at least for the subject involved" (14r). To desire something is to want to have something in order to satisfy certain needs. An act of questioning, in contrast, "does not want to have anything" (14r).

When I put a question my wishing refers under no circumstances to the predicated object that is called into question. E.g. when I ask "Is this wine?", it might very well be the case that I desire to have wine. But this desire can of course not be what the question could be about. (30v)

Certainly there exists such a thing as the wish or desire to acquire a stock of knowledge, and this is "without doubt present in most questions which one in fact puts" $(30 \mathrm{v})$. But then, as we shall see below, the desire for knowledge serves at most merely to motivate the questioning act: it accompanies it as an optional extra. "A question can carry with it a desire for knowledge, but it cannot consist of such a desire" (14v). Questions may thus occur not only as moments in complexes which include also moments of striving but also outside formations of this kind. It is perhaps misleading to invoke here "questions completely lacking in interest" or engagement, of the type of the conventional "How are you?" (25r). Consider, however, questions which one individual addresses (by proxy) on behalf of another, without himself being interested in what the answer might be. Clearly, my question becomes transferred into the realm of desire or striving only in case the answer toward which it tends "contains information which matters to me" $(23 r) .{ }^{21}$

\subsection{Questioning Act vs. Wish}

Similar remarks can be made also in relation to the identification of the act of questioning and of the wish. Certainly there are similarities between the two phenomena, for unlike desire, which typically involves a tendency to take control or possession of an object, the wish and the question both remain in a certain sense at a distance from the world of things. Moreover,

${ }^{20}$ Wissenschaftslehre, 1837, 72. Even for Husserl one meaning of the term 'question' is that it "signifies a certain wish" (A 423/616).

${ }^{21}$ Löw $(1928,435)$ also draws a sharp distinction between strivings and questions and there are reasons for supposing a Daubertian influence on Löw's otherwise rather confused article. For Löw's teacher, Alexander Pfänder, was, by the end of the '20s, Daubert's only philosophical discussion partner. Löw was also an editor of the Festschrift for Pfänder's 60th birthday with Daubert as prospective contributor. See once more Schuhmann and Smith 1985. 
questioning and wishing are equally, as Daubert puts it, "clarified as to their target" (14r). It is impossible that one should wish for or ask about something entirely indeterminate in the way that one may experience indeterminate strivings or "dark desires." This is because wishing and questioning are tied to their linguistic expression..$^{22}$ Thus they must in each case have a structure reflecting, at least in part, the grammatical structure of a corresponding sentence, and they must also have a quality of being condensed or focussed in reflection of the specific word-meanings employed. Both of these features are normally absent from the realm of desires or urges - as indeed from acts of perception - which, as it were, overflow any linguistic packaging in which we might try to contain them. As Daubert writes, it is common to acts of judging and of questioning that in them "subject and predicate are fixed, not flowing as in perceptions and memory" (34r).

That the wish and the question cannot he identified is clear, however, from the fact that the wish can much more easily rest complete in itself, can be a "pious wish" which entails no consequences (28r). Daubert's examples here are derived from the realm of politics ("May our town continue to move forward into the future!" "May our country never be short of such men!") and from children's letters to Santa Clause (14r). The question, in contrast, necessarily implies a "tendency toward decision" ( $21 \mathrm{r}$, $28 \mathrm{v})$. Moreover, a questioning act may itself be embedded in an act of wishing - "I'd like to know how you feel about this" — while a wish cannot similarly be contained within another wish. And finally "there exist indirect questions which deliberately do not directly ask what one wants to know. But there exist no indirect wishes, no indirect questioning desires" (37r).

\subsection{Questioning Act vs. Brentanian 'Phenomena of Interest'}

Wishes, desires, strivings, all belong to one and the same class of psychic phenomena, called by the Brentanists the class of "phenomena of interest." Brentano asserted of such phenomena - and Daubert follows him on this point - that they essentially and always permit of qualitative opposites. Thus they are characteristically designated by paired expressions - "phenomena of love and hate," "phenomena of pleasure and displeasure", etc. - which serve as a means of drawing attention to this polarity. ${ }^{23}$ These oppositions are, as Brentano points out, not a matter of

22 "It seems that whatever we may want to ask must allow of expression in language" (27r). Questions arc therefore "language-dependent" in the sense of Delius 1982.

${ }^{23}$ See, e.g., Brentano's lecture "On the Origin of our Knowledge of Right and Wrong" of $1889, \S 21$. 
any contrast between the objects of feeling acts. They are "oppositions in the relation toward the object." ${ }^{24}$ Desires, wishes and strivings are all positive versions of the pertinent feelings, standing opposed to negative phenomena such as aversion, disgust, repugnance. If, therefore, one wanted to identify the act of questioning as a phenomenon of this sort, then here, too, it would be necessary to point to the existence of this same qualitative opposition on the side of the act. But the question "has no qualitative counterpart" (1r), it manifests no duality of opposites in the given sense. The answer sought for in the question may of course vary as to the value it possesses for the subject. "I can be afraid of the knowledge which will be brought by the answer to a question. I can also strive against a question's being decided" (14r), but the question itself is not corresponddingly affected by changes in attitudes and expectations of this sort. "There are questions whose answer I await with hope or fear. But the question thereby always remains one and the same" $(30 \mathrm{v})$, it cannot be intrinsically modified by opposing acts or states:

If questioning were to be a type of wishing or striving or something related to these, then it would have to be an urge which does not participate in the modifications of pleasure and displeasure, intensity and temperament, in which no inner involvement of the subject is present, whose goal is never unclear, and of which there exists no qualitative counterpart (30v).

The upshot of all of this is summarized in Daubert's remark: "Strivings, desires and wishes belong to a psychic domain which is entirely different from that in which acts of questioning occur" (14r).

\section{§3. The Question as Logical Formation}

\subsection{Question and Judgment}

In order to determine the specific structure of the act of questioning, Daubert, like Husserl, investigates the relation between this act on the one hand and overt uses of language in asking or interrogating on the other. Husserl's conception of this relation had been particularly cumbersome: he had identified the question-sentence as a (disguised) judgment registering the existence of an act of questioning as an object given in inner perception. Thus in Husserl's view a question "is Erna married?" is equivalent to the statement "I perceive myself as asking whether Erna is married." ${ }^{25}$

${ }^{24}$ Brentano 1924/25, II, chap. 7, §9.

${ }^{25}$ Note that this equivalence implies, as Husserl himself recognizes in passing, that all question-sentences have a meaning that is indexical: all such sentences are supposed to express deictic judgments about certain current acts on the part of the questioning sub- 
Daubert, however, denies the necessity of restricting the class of meaning-bestowing acts to "representations." ${ }^{26}$ Thus he can reinterpret the relation between question-sentence and questioning act in such a way as to allow the latter, despite the fact that it is not objectifying, to be that which bestows meaning on the former. The question-sentence can thereby be said to express a questioning act in just the same sense in which a judgment-sentence expresses an act of judgment.

Daubert's criticism of Husserl here is quite outspoken: "When I put a question and utter it, do I then utter something about my experiences?" (32r). "According to Husserl, a question would be the taking notice [of an experience], it would be an objectifying act, and thus it would not differ essentially from a judgment - where it is this very difference which has to be worked out" (30r).

The link between question and judgment was customarily sought in the connection between question and answer. Thus, according to Meinong, he who asks a question wants to receive an answer, that is he wants "to reach a corresponding . . . judgment" $(1910,124)$. And indeed in Rickert's view: "The necessary structure of the ideal judgment in relation to the goal of truth is best made clear of one sees the judgment as the answer to a question" $(1904,95)$.

Daubert concedes that questioning act "seeks in some way to get beyond itself" (1r): it "presses towards a solution" (25r). But one may reasonably doubt whether "the peculiar attitude which lies in answering a question" truly represents "the original type of the judgment" (78v). For the judgment does not normally occur as a reaction or sequel to other acts, or as supplying the fulfilment for acts which precede it, and it certainly need not do so. The answer, in contrast, must of necessity supply some sort of fulfilment for a preceding question.

Where Rickert wanted to oppose question to judgment by seeing the one as prior to the other, Sigwart saw the difference as lying in the opposition between intention and realization, conceiving the question as "the draft of a judgment, or as an attempted judgment" whose realization is

ject. Husserl affirms also a relation of "intimate fusion" [innigste Verschmelzung] between this inner perception and e.g., the questioning act - as a means of accounting for the fact that one is not aware that there are two different acts involved (A692/851). Similarly, when a word is understood as being used to name something, "we have before us phenomenologically instead of a mere sum, an intimate unity, in fact an intentional unity: thus we are rightly say that the two acts, the one setting up the complete word, and the other the thing, combine together intentionally into the unity of act . . We must admit that the moments implied in this unity — the physical word-appearance with its animating moment of meaning, the moment of recognition and the intuition of what is named - do not separate themselves off clearly in the intimacy of this fusion, but our discussion compels us to assume them all to be there." (A500/691)

${ }^{26}$ See the Daubert texts from the years 1904 and 1906 translated in Smith 1985. 
the judgment itself $(1904,151 \mathrm{f})$. Here, too, Daubert is willing to concede that questions tend toward completion, "toward the resolution of a certain uncertainty" $(73 \mathrm{v})$. But this uncertainty functions again at best as the motive which triggers off the question and "the sense of the question-sentence contains no reference to the issue of whether it is with this or that motive etc. that the question is put" (25v, our emphasis).

Hermann Lotze gets closer to a correct account of the relation between question and judgment when he conceives both as expressing an identical logical content which he sees as consisting in a subject-concept $(\mathrm{S})$ and a predicate-concept $(\mathrm{P})$ joined together by a certain relation. ${ }^{27}$ This identical content can be merely assumed or entertained, can be posited as merely possible or as undecided. Once it is 'decided', however, then the content must of necessity take on one of two judgmental forms, actualizing one of two mutually exclusive possibilities, either affirmative ( $\mathrm{S}$ is $\mathrm{P}$ ) or negative ( $\mathrm{S}$ is not $\mathrm{P}$ ). And now, as Lotze would have it, the identical logical content that is here affirmed and there denied can be seen to have been expressed already in the question sentence "in a form that is still free of affirmation and negation. ${ }^{.28}$

\subsection{Judgment and State of Affairs}

When, however, Lotze goes on to affirm a tripartite division of sentential phenomena into positions, negations and questions, then his view becomes untenable, if only for the reason that "negation can occur also in the question itself" (7r). A question of the type "Is Mulligan not here?" is surely as legitimate as one of the type "Is Mulligan here?" The logical structure of both position and negation appears not only in the judgment but also in the question, and this communality of logical structure reflects a communality of structure as between the acts which both sorts of sentence express. ${ }^{29}$

Daubert follows Husserl in recognizing that in speaking of questions or judgments one can mean either actually occurring conscious acts or ideal meaning-formations. Whereas the act can be studied by empirical means

${ }^{27}$ Daubert, too, shared this traditional subject-predicate theory of judgment, though he is aware of its limitations, e.g., in regard to one-membered judgments, questions, commands etc. See $38 \mathrm{r}, 77 \mathrm{r}$.

${ }^{28}$ Lotze 1912, §40: "In a judgment we think through a certain relation between $\mathrm{S}$ and P . . . This relation constitutes the content of the thought, about which then two mutually contradictory subsidiary judgments are made, the one affirmative, giving it the predicate of validity, the other denying it this predicate. This content has its own expression, still free of affirmation and negation, in the question-sentence."

29 Thus both question and judgment are subject also to modalizations: "Must A be B?" "Is A really $\mathrm{B}$ ?" (24r). 
and procedures, the ideal meaning-formation demands a different sort of analysis, just as geometrical figures demand an analysis different from that which is appropriate to empirically existing shapes. The ideal meaning-formation is what is irrespective of whether any of its possible instantiations actually exist. Moreover, one and the same ideal meaningformation can be grasped - in reading or in hearing $(27 \mathrm{r})$ - by different individuals and at different times, and hence also there can be established that link between questioner and questionee which makes possible the question as social formation.

Both judgment-sentence and question-sentence, now, are the linguistic expression of meaning-formations of a specific type. These ideal meaningformations are moreover complete in themselves. The incompleteness usually and rightly ascribed to questions as the feature which distinguishes them from judgments does not reside in the domain of meaningformations: the meaning of the question-sentence is perfectly understandable, definite and well-circumscribed as it is in itself. Incompleteness arises only when we move beyond the sphere of meanings and consider the relation between questions or questioning acts and their objectual correlates. It pertains to "the way in which [questions] take stock" of the things they are about (18r), to the way in which they point outwards and are bound to things.

How, then, are judging and questioning acts related to their objects? As Daubert puts it, both judgment and question move "purely in the realm of things" (14r). Both are distinguished from acts of perception by the fact that, where perception makes accessible the things as they are in themselves, with their parts and moments and "the relations which tie these together in the unity of the thing" $(1 \mathrm{v}),{ }^{30}$ judgings and questionings are correlated - in different ways - with sui generis objectual formations called Sachverhalte or states of affairs. Such states of affairs do not belong to a special realm, separate from or transcendent to the realm of things. For just as, according to Daubert, the judging or questioning act is founded on perceptions, ${ }^{31}$ so the object of such an act, the state of affairs, is founded on things perceived, obtains only "through the things and their objectual relations" $(79 \mathrm{v}){ }^{32}$

\footnotetext{
${ }^{30}$ On Daubert's views on perception, which in some respects anticipate the ecological theory of J. J. Gibson, see Schuhmann and Smith 1985.

${ }^{31}$ It can be executed only "with regard to given and perceived things" (74v).

${ }^{32}$ Thus on p. 18r Daubert refers to states of affairs as "Gegenstandsverhalte."
} 


\subsection{Thing and State of Affairs}

It is as if the act of perception focusses on a certain slice or segment of the material world. Through its constituent meaning-acts the judging act then imposes a certain quasi-grammatical form upon this segment. Thus in the simplest case it throws into relief a certain element in the total object of perception "as something which becomes the subject, to which a determination is then related" $(74 \mathrm{v})$. In cases such as this, therefore, the act of judging cannot transgress the boundaries prescribed by perception. It is however free to pick out any element within these boundaries and to fix this as its subject. Daubert contrasts this freedom of the judging act - which carries over also to the act of questioning - with the dependence of perception upon things:

Materially the thing has its activity. This has its modes and they have their peculiarity and this again has ... . etc. Nothing can he changed in these material foundation relations. But conceptually the whole thing can be inverted, e.g., the suddenness of the increase in the velocity of the motion of the machine. The suddenness is here the member which is determined by all the others. But not any arbitrary ordering is possible. ("The suddenness of the motion of the velocity of the machine of the increase" is impossible.) (63r $)^{33}$

A judging is, we said, a specific sort of representation of a state of affairs. This representation is, as Husserl makes clear, not

a mere succession of presentations, but rather a judgment, a peculiar "unity of consciousness," which "binds" the presentations. And in this binding together there is constituted for us the consciousness of the state of affairs. To execute a judgment and to be "conscious" of a state of affairs in this way are one and the same. (A441f./632)

A judgment is an act of "fixing a subject and a predicate" (34r, 40r). But the part or moment that is fixed on as subject need not in itself be a bearer of properties, it may be even less substance-like than its predicate. The subject is simply that member around which the judgment is centred, "is that about which I say something or that starting from which I think something" (63r). Thus the judgment is able to assert how things stand without being forced to "picture the relations which objectively make up the unity of the thing" (63r).

To capture this opposition between how things stand in themselves and how they are asserted to be in our judgments, Daubert now distinguishes between the Sachverhalt and what he calls the "Erkenntnisverhalt," the "state of affairs as cognized" or as "unfolded" in cognition (17v). The former is the objectively existing structure of things, properties and rela-

${ }^{33}$ Daubert's remarks here echo the account of the (relative) freedom of categorial forming and shaping put forward by Husserl in the 6th Logical Investigation. See especially $§ 62$. Already on p. 1v Daubert refers explicitly to the difference between material foundation relations and relations of predication. 
tions as they are in and of themselves. The latter is that side or aspect of the former which serves as the immediate objectual correlate of a given concrete act of judging, the medium through which the relevant things and properties are given to or delineated by the judging subject.

That element which serves as focus for the judgment accordingly exists in the Erkenntnisverhalt as something thrown into relief in relation to the other members. Thus consider: "The chairman opens the meeting," "The chairman is opening the meeting," "The meeting is being opened by the chairman," "The opening of the meeting is being conducted by the chairman," "The chairman has opened the meeting," "The meeting has been opened by the chairman" $(17 \mathrm{v}, 63 \mathrm{r})$. Each of these sentences differs as to its associated state of affairs as cognized, but they are in fact concerned with one and the same objective Sachverhalt.

\subsection{State of Affairs as Questioned and State of Affairs as Cognized}

We have, then, a difference between an objective state of affairs and a state of affairs as cognized, a difference which turns above all on the fact that an element of the latter is emphasized, comes to the fore in reflection of the judging act that is directed towards it. ${ }^{34}$ But now analogous differences offer themselves also if one considers the relation between this same objective state of affairs and the objectual correlates of corresponding wishes, commands, presumptions, and so on:

The chairman has opened the meeting. He has not opened it. He must open it. Or: Has he opened it? If only he would open it. He should open it. He is allowed to open it, etc. Common peculiarities one can distinguish here are:

1. the act of thinking ...,

2. the thought itself, a peculiar ideal sense-formation: the wish itself, command, question, assertion, declaration itself . . . which "becomes an event" in the act,

3. the corresponding sentence, which by means of its meaning expresses the thought,

4. something towards which the thought is directed . . something which the assertion puts forward as there ... which the question puts forward as questioned, the wish as wished (2r).

This passage represents an interesting further generalization of the notion of state of affairs. For Daubert is now affirming that the immediate correlate of these acts is not the Sachverhalt as such but a sui generis Frageverhalt, Wunschverhalt, etc. (17r) - a state of affairs as questioned, as

${ }^{34}$ We leave open here whether other differences are involved also: see Smith 1987 for a discussion of this matter from the point of view of the work on states of affairs of Daubert's fellow Munich phenomenologist Adolf Reinach. 
wished, as desired, and so on. ${ }^{35}$

A question asks what is the case, i.e., it asks something about the way things are objectively $(79 \mathrm{v})$. But that which directly corresponds to the question, the medium through which the things referred to in the question are given to the subject, is not any full-fledged objective state of affairs, replete in all its manifold determinations: otherwise it would be pointless to ask the question at all. The immediate objectual correlate of the question is only the state of affairs as questioned. "When I ask a question the objects become unfolded to me as asked" (38r, our emphasis).

It is important to stress that Daubert's theory of the Frageverhalt does not imply that he has adopted, after all, a Husserlian view of the meaning of the question-sentence as a matter of objectifying acts. The Frageverhalt is not the object of the questioning act. In questioning we rather open up a certain structure on the side of the objects - and then it is necessary to distinguish carefully between, on the one side, questioning, and on the other side, a possible reflective registering of this question or of the objectual structure that is constituted thereby. It is only the latter which could quality as an objectifying act in the sense of Husserl's theory (cf. 28r, 48r, $85 \mathrm{r}){ }^{36}$

The relation to states of affairs is not confined only to judgments and questions. It applies also, e.g., to requests and commands, as is shown by the fact that they, too, come to expression "in a sentence having a sentence-meaning" (36r). Requests and commands are however set apart from questions by the fact that they are typically not involved in the cognition of states of affairs. But then how precisely is the cognitive character of the question to be understood? The state of affairs as questioned has, we said, been brought only to a certain degree of determinateness: it is still in some respects "open." It is not however as if the act of questioning would merely be a registering of some locus of indeterminacy in a structure of this sort. ${ }^{37}$ In questioning we aim rather at the "material fixing [sachliche

${ }^{35}$ A similar idea is put forward by the Meinongian Otto Tumlirz in his 1919. Tumlirz defends a theory of Interrogative in extrapolation, within the framework of the theory of objects, of the Meinongian notions of Objektive, Desiderative, Dignitative, etc. See also, for a more general treatment of questions within the Meinong tradition, Kreibig 1914.

${ }^{36}$ Daubert describes the way in which the question is referred outwards to the world of things as its "sharp edge [Zuspitzung] which is it the same time an opening [Öffnung]" in relation to "the is and the is not of the Sachverhalt" $(85 \mathrm{r}, 25 \mathrm{v}$; see also $42 \mathrm{v})$. The terminology of "Öffnung" seems to be one of Daubert's own coinages. It is then employed also by Adolf Reinach in his work on premeditation (Part I, p. 186, Part II, p. 32). Compare also, e.g., D. Wunderlich's recent work on speech act theory: "It is an important thesis that the propositional content of a question is an open structure" (1976, p. 188)

${ }^{37}$ The term "locus of indeterminacy" is taken from Ingarden (1931), whose views in this respect are remarkably similar to those of Daubert. Ingarden studied in Göttingen not 
Fixierung]" of this structure (80r), at the establishing of a structure that would be more fully determinate. The question is not itself the fixing or establishing, but that which sets the latter in train. Indeed to the contrary: that which is to be fixed or established remains open in the question, and it is essential that this should be so.

The unfolding or opening up of the relation, e.g., between an S and a P, is not performed for its own sake. It is performed in order that it should once more be closed, and the act of questioning manifests, in this respect, a certain dynamics. It aims towards a closure of a sort that can be effected only through judgments (21r), and Daubert refers to "the knowledge that is dammed up in the question," an image which picks out nicely both the static structure of the question and also its tendency to flow over into something else (18r). This does not however imply that, as Husserl has maintained, questions "aim at judgments" (A423/6 16). Rather, the question is directed "toward something that is given in a judgment but is not itself a judgment" (27r). It is necessary to insist upon this distinction, for while judgments may effect a closure, they cannot themselves be identified with this closure. A question involves "the desire or need not of a judgment, but rather ... of that which the judgment presents in cognition or affirmation" (73r). A question can thus quite properly be answered by something other than a judgment, as when Tom responds to Jim's question "What time is it?" by lifting up his wrist and showing Jim his watch. What the judgment presents we have already met: it is the Erkenntnisverhalt, the Sachverhalt as cognized, and thus we can now say that it is towards formations of this kind, or towards a move from the relatively open Frageverhalt to the relatively closed Erkenntnisverhalt, that questions aim.

\section{§4. The Directed Question}

\subsection{Question and Communication}

As we have already seen, Husserl has maintained of sentences expressing questions, wishes, commands, etc., that they acquire their meanings from special, inwardly directed objectifying acts. Daubert, in opposition to this, asserts that in the normal flow of things "no reflection upon my judging, questioning, wishing or commanding takes place":

The carriage is driving up. Is the carriage driving up? If only the carriage would drive up!

only under Husserl but also under Reinach, and his views are in many respects close to those of the Munich school. That he was aware at least of Daubert's existence is shown by the reference in Husserl 1968, 143. 
The carriage should drive up. In all cases it is a matter of the carriage and its driving up, and this already in a special relation. The carriage is the subject and the driving up the behavior [Verhalten], which is in the one case affirmed of it as existing, or questioned, or commanded. (36r)

Reflection on the judging or questioning act can of course occur retrospectively. Then, however, the judgment or question already exists as a self-contained phenomenon. And that it is the question itself and not the questioning act which is then the object of reflection is shown in the standardly impersonal form of the linguistic expression of such reflection: "The question is ...," "It is questionable whether ...," etc. (77r).

Commands differ, now, from judgments and questions in that they include of necessity a certain relation to some alien individual or individuals. As Daubert says:

In the optative and in commanding something is expressed which, no matter whether we consider the wish or command of a human being or of a subject in general, concerns the relation of this subject to others. This differs from the pure question, which contains nothing of such a relation and remains, exactly like the judgment, wholly in the sphere of things. (36r)

Clearly, however, it is built into the question, as also into the judgment, that it can go beyond the mere relatedness to things and exercise a function in the context of an individual's behavior towards his fellows. Just as the judgment acquires a new sort of completeness when, in appropriate circumstances, it becomes an uttered, addressed judgment, so the question acquires a new sort of dynamic when (again in appropriate circumstances) it is directed towards another who is called upon to supply an answer. ${ }^{38}$

The question as utterance addressed to an alien subject is called by Daubert the Anfrage or "directed question." It corresponds to the judgment as declaration or assertion, as imparting of information, as contrasted to what we might call the pure judgment, an event which might occur even within the solitary life of the soul. And now, the directed question can no longer be set apart from, but on the contrary runs "parallel to, wishes and commands" (36r). ${ }^{39}$

38 "In appropriate circumstances," here, means, e.g., that the phenomena in question involve reference to objects which are familiar or at least accessible to the individuals involved.

${ }^{39} \mathrm{Cf}$. also 73v, 78r. Reinach is making the same point when he affirms that "the act of questioning is a social act" $(1913,709)$. 
The distinction between question (Frage) and directed question Anfrage is present also in Husserl: "The meaning of the question-sentence remains identical whether we are dealing with an internal or a directed question." (A683/843) What, however, is for Husserl no more than an incidental remark, represents a cardinal point of the Daubertian theory. Above all, Daubert moves significantly beyond Husserl in pointing out that questions function in the full sense only in a context of intersubjective communication, and it is to this aspect of his theory that we now turn.

\subsection{Question, Answer, Solution}

A question, as we have seen, "need not have an address" (78r). It can occur even where there is no addressee, where it is put "in silent thinking" (30r). That specific formation which is called the directed question is however characterized by the fact that "it addresses someone and calls for information from him" (30r, cf. 45r), "aims at being answered by another individual (be it real, general, ideal or fictitious)" (37r)..$^{40}$

Directed questions are not, however, simply a special type or sub-class of questions in general. It is not as it one could distinguish between personal and objectual questions in such a way that the former would turn for information to other persons while the latter would "seek information from the facts themselves" (30r). A view of this sort is untenable, since even though things do in a certain sense make possible the consciousness of states of affairs, they do not themselves furnish information: it is "only in an extended sense that the things give answers to questions which are

40 Compare Pfänder 1909 and also the following note by Daubert on the occasion of a discussion with Pfänder of 20.IV.1911:

Judgments, questions, wishes, commands, demands, announcements of obligations, refusals, invitations, requests, ... permissions, prohibitions, sentences expressing cans and musts: how do these stand to each other?

1a. They may be addressed to someone definite in the case of requests, invitations, commands...

1b. They may be addressed to some indeterminate person: requests (please wipe your feet), invitations (dinner is served), permissions (smoking allowed), prohibitions (cycling forbidden).

In either case the wish, command, etc. is directed at the behavior, the action (commission or omission) of persons, whether determinate or indeterminate.

2. Another group of cases is that in which what is called for concerns entirely the material make-up or occurrence of things. (38r, our emphasis) 
put to them" (25r). ${ }^{41}$ This implies, however, that the assertion "“A question aims at an answer' is true, properly speaking, only in the case of the directed question" (25r): the question as logical formation aims, rather, at a 'solution' (38r). ${ }^{42}$

Even this distinction, however, presupposes that both the question and the directed question would aim equally at a cognitive completion, be it a solution or an answer. But this seems to stand in conflict with the existence of questions like "May I come in?", "May I leave?", where "my aim is not knowledge, but permission" (30v). Even here, however, Daubert insists that while it is certainly true that not all directed questions aim explicitly at the rectification of a cognitive deficiency, all achieve their purpose nevertheless "via some knowledge" (30v). Whatever my directed question is looking for - permission, reassurance, advice - the answer will always, willy nilly, also make some contribution to my knowledge: "He whom I have asked, when he gives me the information, tells me something about the things" (25r), and I may even, in certain circumstances, be able to pass on what is then communicated to me to the benefit of others. An answer therefore contains within itself an object-directed solution, which is to say that an answer, to be an answer - i.e., to be the counterpart ['Gegenwort'] to a question and not merely any old (possibly inappropriate) response - must function in the service of resolving the question that has been raised $(45 \mathrm{r}, 30 \mathrm{v})$. And correlatively: the question as logical formation is not some supernumerary entity, existing apart from the directed question: it is contained in the latter as a distinguishable part.

The directed question therefore consists (in the standard case) in:

(1) a questioning act,

(2) a certain identical logical formation (an ideal meaning),

${ }^{41}$ Daubert is here reacting against his teacher Theodor Lipps, according to whom the process of gaining knowledge is an "interrogation of the objects. The objects give answers to our questions this or that answer according to the direction of our interrogation" (1905, $59)$.

${ }^{42}$ It is interesting that the term 'solution' is correlated not with 'question' but rather with 'problem'. This last term has its origins in Proclus' commentary on Euclid, where it denotes an exercise in geometrical construction. Such an exercise is always formulated impersonally: it is stated simply that this or that should be carried out. Bolzano, who was probably Daubert's source here, distinguished questions from geometrical exercises ['Aufgaben'] by the fact that what is demanded by the former is a sentence, not, e.g., the construction of a figure (Wissenschaftslehre, vol. II, §145). Daubert discusses this distinction on 85r. Bolzano himself adopted the terminology from Lambert (Neues Organon, vol. I, Leipzig 1764, 100), and his use of it shows clearly that he was not aware of the essentially intersubjective nature of the question. 
(3) an utterance directed to some alien subject,

and (2) and (3) are essential if the act is to be received and understood by the subject to whom it is addressed. ${ }^{43}$

Daubert holds, then, that the directed question includes of necessity a questioning act. A stronger position, found only in germ in Daubert's manuscripts, would see the questioning act as being itself tied intrinsically to its being addressed to some other person. Talk of "putting a question in silent thought," on such a view, would be as metaphorical a usage as would, e.g., our talk of questions being answered by facts in the world, and Husserl's "solitary acts" could count at best as meditations, deliberations, broodings, ruminations: they could not be acts of questioning in the strict and proper sense. Such a view would imply also that it is not directed questions but silent interrogations which would turn out to be the nonstandard or derivative formations. They might be interpreted as cases of the sort mentioned earlier, which are such that the individual toward whom they are directed is merely fictitious (the product of an artificial opposition between an 'I' and a 'me').

\subsection{The Phenomena of Interest}

Questions may still function in various ways when separated from the context in which they are raised by one individual and addressed to another. They may appear, e.g., in text-books, or as grammatical examples. The original question is thereby modified and in a certain sense impoverished by being withdrawn from its natural surroundings. There are however also certain kinds of social situations where "one manipulates with questions without strictly asking them" (71 v), where a question is inserted in a context in which it is "dishonest . . . and spurious" (78r). Adolf Reinach, Daubert's friend and associate in Munich, took the view that social acts of this kind are not questions at all, but merely pseudo-questions [Scheinfragen] masquerading as such. ${ }^{44}$ Daubert however insists that even in such cases the content of the question, the question as logical formation, remains intact and unchanged; it is a "rigid incarnation," immune against the specific treatment it may undergo from environment to environment $(36 \mathrm{v})$.

The difference between a question as functioning normally in being addressed to a questionee and as removed from this context is a matter of

${ }^{43}$ See Reinach 1913, 707, and also, e.g., Lyons: "To ask a question of someone is both to pose the question and, in doing so, to give some indication to one's addressee that he is expected to respond by answering the question that is posed. Hot the indication that the addressee is expected to give an answer is not part of the question itself." $(1977,755)$

44 1913, 709f. 
what Daubert calls it's 'animation. ${ }^{45}$ Thus the question as grammatical example is, he writes, cut off "from its living connections and its sources" $(78 v)$. That which remains of the total question-phenomenon is no more than "an empty form, filled with inauthentic life" (52r).

The "addressing" of a question is not a neutral phenomenon. Questions do not arise anonymously and at random, but through deliberation, in reflection of specific interests, motives, circumstances ${ }^{46}$ The interests which underlie the asking of a question may vary widely from case to case, something which accounts for the large variability in the character of one and the same question when addressed at different times to different subjects. ${ }^{47}$ Thus one and the same question "can be embarrassing, or pedagogically helpful (Socratic), or conventional. It can be benevolent or hurtful or curious or sympathetic or objective." (79r).

Among the host of intentions that can be combined with and accompany the asking of questions, Daubert mentions the goal of obtaining an authoritative answer, the goal of finding out the opinion of the addressee, the goal of trumping the addressee with a question he cannot answer, the goal of having an utterance repeated or of making sure that one has understood it ("Is what you say meant in this sense?" "That is surely not to be taken seriously?"). He mentions questions which anticipate their own answer ("It was lightning, wasn't it?"), questions eliciting protest ("You're surely not going to go?"), questions involving a presumptive challenge ("That's okay with you surely?"), questions expressing impatience ("Have you nearly finished?"), and diplomatic questions where the

${ }^{45}$ Here Daubert once again explores for his own purposes terminology introduced merely in passing by Husserl. In his reduction of expressions to the 'objective' remnants which they display even in the solitary life of the soul, Husserl hit upon the problem of indexicals ('occasional expressions,' as he called them), of which he had to concede that their meaning "can be derived only from animate speech and the manifest circumstances belonging to it" (A82/315), our emphasis). Thus where for Husserl — at that stage — it is expressions involving 'I,' 'now,' 'here,' etc., which are limiting cases of language use, for Daubert it is rather Husserl's 'objective' expressions which are marginal. With this, Daubert from the very beginning breaks through the framework of Cartesian representationalism (and indeed solipsism) within which Husserl operates.

${ }^{46}$ See Harrah 1969 for an elaboration of some implications of this fact for the logical treatment of questions and answers.

${ }^{47}$ This is a well-known phenomenon, and Daubert is not the first to elaborate on it. Traditional treatments have however too often been restricted to the consideration of those species of questions which are relevant for gaining knowledge independently of context. Thus while Aristotle, for example, distinguished four types of questions "whether A is?," "whether A is B?," "why?," "what?" (Posterior Analytics, Book II, chap. 1), his interest is focused exclusively on "scientific" questions for which person and context are entirely irrelevant. The same goes for Giordano Bruno who (in his De Lampade combinatoria Lulliana, Wittenberg 1587, chap. 9) expanded this list to ten (see also Herbert of Cherbury, De veritate (1645), pp. 161-98), as also for Arnold Geulincx, whose Logica restituta (Leiden 1661, Part IV, section I) reduced it back to one (“what is it?"). 
questioner is interested not in being informed either about things or about someone's opinion but rather in eliciting from the addressee, via his answer, some background information that is not directly expressed (12r, $37 \mathrm{r}, 45 \mathrm{r}, 77 \mathrm{r}$ ).

From the meaning of the sentence alone "one cannot gather whether the determination which is asked for is intended as a supplementation, as an instruction, or as an elucidation" (71r). The interest on which the question is founded - it may be a "desire for certainty, elucidation, understanding, clarification, repetition, etc." (37r) - therefore merely underlies and permeates the questioning act: it does not in fact appear in its content.

Daubert distinguishes two levels of such interest phenomena. On the one hand "the question wants to be decided" and it hides "a will to decision" (24v) or a "will to clarification" (25r): "I ask because I want to know" (42r); "What is intimated [kundgegeben] in the question is the desire for an answer" (12r).$^{48}$ Thus where, as we have seen, questions as such are not analogous to wishes and commands, they may be associated with such phenomena in the case of questions as directed (cf. 43r, 70r).

The action of addressing a question is a temporal event and so, too, the volitions and desires directly associated therewith have a correspondingly short-lived existence. They are however, as Daubert puts it, "subtended" [unterspannt] by more general and enduring intentions which he calls "tendencies or directions of interest." Thus we have an immediate dependence of the questioning act upon an associated interest, an episodic will or desire, the latter being dependent in turn upon an underlying tendency. "Such a tendency is not an additional, separate act" (41r). It is rather an enduring mental state which underlies and governs the concrete movement of thought (cf. 64r): a state of curiosity in regard to a given object, a volitional state in regard to a goal one wants to achieve. ${ }^{49}$

"It is easy to see that we have now left behind the logical sphere," as Daubert himself notes (26r). This does not however mean that we must relapse into the old doctrines of psychologism. Daubert remains firm in his view: "The question as such is not a striving and not an urge" (48v), nor is it "the will to know as such" (21r): "a question, although it is bent on something, is not properly speaking an act of will" (85r). Certainly

${ }^{48}$ Daubert's use of the term "Kundgebung" here is derived from Marty (see, e.g., his 1908) and anticipates both the work of Bühler on the dimensions of meaning and also, in a certain sense, the saying/showing doctrine of Wittgenstein.

49 Daubert's discussions here parallel the work on "Einstellung" or "mental set" of the Wurzburg school, and specifically the work of Selz (also a member of the Munich group headed by Daubert). See esp. his 1913 on the ordered course of thinking and problemsolving (e.g., 130ff., 140ff.). 
"the directed question, when functioning in communication, stands midway between desire and the question properly speaking" (37r), but the process of knowledge, i.e., the interplay of questions and answers, while it may he regulated by my interests is from the point of view of its content unaffected thereby, being determined exclusively by the objects cognized. The interest itself therefore does not appear in the question in the purely logical sense, it is not objectified or expressed therein. As Daubert writes:

The searching interest is not registered (that would be a judgment about it). I even do not consider it at all. It functions both in the question and in the judgment, but evidently in quite different ways. In the question it functions as that which gives life to the whole act. The question is the act of searching become logically self-contained and set apart. (58r)

\subsection{The Phenomena of Emphasis}

Answers, too, are motivated by interests, for while an answer should say how things are, i.e., should be a judgment about the things, such a judgment may take shape as "an assurance, as a giving of information, as a decision or declaration, all occurring under the form of an assertion" (45r). It is important to stress, however, that interests and interest-tendencies play a double role in the process of producing both questions and answers. On the one hand they determine the intentions of the subject (in making him turn in this or that direction). On the other hand however they determine precisely which objectual correlates come into play in any given case. As has been said already, a state of affairs as cognized always develops out of the perception of given objects; these objects become, as it were, grammatically focused and organized, particular elements being set into relief through our judging acts:

When I look with a certain interest at some object in order to gain knowledge thereof, then the object does not fill into my gaze as something which exists on its own accord; the object rather develops in reflection of my considerations of it $(18 \mathrm{v})$.

Not, of course, as if the object would change in reflection of my acts. Rather, it unfolds itself as my interests direct me to specific elements as subjects, establish centres of gravity in the complex of things before me, underlining certain features while neglecting others. ${ }^{50}$

This determinate shaping of the state of affairs as cognized or questioned manifests itself linguistically in the distribution of emphasis or

${ }^{50}$ Ingarden, too, distinguishes 'objective' and 'intentional' states of affairs, and sees the latter as reflections of interests. See chap. 11 of his 1964/65 and also Smith 1978. 
intonation to which the judgment or question as utterance is subjected. ${ }^{51}$ On the one hand, emphasis does not interfere with the meaning of the question-sentence, i.e., with the question considered as a purely logical formation. "The animated sense of the sentence is made up of the interestguided emphases which, however, do not disturb the sentence-meaning and its structure" $(37 \mathrm{v})$. The animated sense has much rather a function in the ordering and development of the cognitive process. It serves to ward off confusions on the part of the addressee, "confusions which would otherwise threaten in the course of broader connections of cognition." It serves "to mark out areas of clarity," to underline "that which is the point in contrast to that which goes without saying," to draw attention to the kind of response which will be appropriate in the given case (20r, 17r)..$^{52}$

Consider, for example, the questions "Is Mulligan ready?" and "Is Mulligan ready?" The logical content of these two questions is identical. On being addressed, however, they function in entirely different ways. The first presupposes a sort of communication in which Mulligan is talked about and where it is questionable whether he is ready. The second, in contrast, presupposes the situation: someone is ready; what is questionable is whether it is Mulligan. Emphasis can thereby effect a psychological transformation, an adjustment of our expectations which enables the cognitive or inquisitive interest "to be sustained even through far-flung connections" (52r). The course of inquiry can itself be seen as a sequence of transformations of this sort, leading from one emphasized figure to the next in such a way that each is successively submerged into the domain of

${ }^{51}$ Among the authors who exerted in influence upon Daubert it seems to have been mainly the Munich linguist Hermann Paul who had treated the linguistic phenomena of emphasis or intonation ['Betonung'] (see his 1920, 123). Emphasis is mentioned in passing also by Husserl as a 'heterogrammatical means' of expression (A684/843). Daubert seems however to have been the first to study the phenomenon on a larger scale from a philosophical point of view (see, e.g., p. 11r of his manuscript A I 5, dated 1902/03). He introduced the theme into the circle of his Munich friends, where it can be traced in writings from 1908. Thus in his report on Reinach's lost habilitation thesis, Husserl refers to "the interesting phenomena of emphasis which are investigated here for the first time". (This report is now published in Mulligan, ed. 1987.) Reinach's theory of emphasis, which applies not only to questions and answers but indeed to judgments in general, is presented in his article of 1911, 244-50 (Eng. trans. §17), which is also the first published presentation of the Munich theory. The notion of emphasis is referred to also in Pfänder 1909 (303), and the tradition has been carried forward into modern linguistics, e.g., in the work of Nehring (1963, Chap. 10 on "Satzmelodie") Cf. also the treatment of emphasis from the Gestalt-psychological point of view in Rausch 1971.

${ }^{52}$ It would be interesting to compare here the ideas of Rausch and other Gestalt-theorists on the ways in which the figure-ground structures of perception, too, may be similarly dependent on the contributions of the perceiving subject. The opposition of figure and ground has recently been taken up by linguists such as Hopper, Wallace, and Longacre and Levinsohn, leading to conceptions of the workings of the sentence very similar to those of Daubert. 
what is taken for granted, so that long-range interests are permitted to govern the process as a whole.

\section{§5. Conclusion}

What, then, is a question, according to Daubert? It is, at any rate, a complex phenomenon. On the one hand it is something subjective, a deliberate activity of consciousness which is (a) fixed in language and (b) in need of completion in the sense that it tends beyond itself towards an answer.

The question considered purely as logical formation, i.e., in abstraction from associated dimensions of attitude, mood, striving, etc., relates purely to the sphere of things: it is not a product of any inward directedness such that it would register, e.g., doubt or uncertainty on the part of the questioner. Its object is not a thing or complex of things but belongs, like that of the judgment, to the family of states of affairs. In the case of the act of judgment this correlate is more precisely what Daubert calls an Erkenntnisverhalt, a state of affairs as cognized, the judgment serving to bind together certain objectively given elements and to pick out and fix some of these elements in relation to others. In the case of the act of questioning this correlate is what Daubert calls a Frageverhalt, a state of affairs as questioned. Here the relevant relation between elements is not fixed or established, but rather opened up - for the purpose of being closed again in an appropriate answer. This aspect of the question implies that it is not, in its most typical or standard manifestation, an isolated event, but rather an integral part of a larger complex of acts extended through time.

The question evinces a tendency to flow over into an answer. This relation of question and answer is not a purely logical affair (the progress from one ideal meaning-formation to the next). It is a specific sort of social phenomenon, the answer being typically supplied by an individual other than the questioner himself, though - unlike most philosophers who have laid stress on this social dimension of interrogative uses of language - Daubert still sees the need to take account of the associated dimension of mental acts, as also of the strictly logical dimension of ideal meanings.

The questioner may in certain circumstances aim at an answer containing information about things in the world. But he can aim also, e.g., at the gaining of permission or of confirmation, according to the specific interest which animates his question. Such interests are not part of the meaningstructure of the question but are merely part of that which is intimated or made manifest by the way in which a question is put in given circumstances - especially via differences in emphasis and intonation. 
The question is, still more summarily, an event brought about in the psychic life of an individual, an event which itself brings into being a tendency to move from a relatively open Frageverhalt to a relatively closed Erkenntnisverhalt. Further, it is necessarily such that it is able to be brought to expression and directed toward another individual with whom the questioner shares relevant common interests. An adequate theory of questions is one which is in a position to cope with each of these aspects: it must not be restricted merely to the investigation of the logic, or the psychology, or the pragmatics of interrogative phenomena, but must find a way of coming to grips with the fact that all of these dimensions are bound together in a quite peculiar way.

\section{References}

Åqvist, Lennart. 1975. A New Approach to the Logical Theory of Interrogatives. Tübingen: Gunter Narr (first published Uppsala: Almqvist and Wiksell, 1965).

Avé-Lallemant, Eberhard. 1975. Die Nachlässe der Münchener Phänomenologen in der Bayerischen Staatsbibliothek. Wiesbaden: Harrassowitz.

Belnap, N. and Steel, T. B., Jr. 1976. The Logic of Questions and Answers. New Haven and London: Yale University Press.

Bergler, Reinhold. 1961. "Zur Psychologie der Frage," Archiv für die gesamte Psychologie 113, 49-65.

Bolzano, Bernard. 1837. Wissenschaftslehre. Versuch einer ausführlichen und grösstentheils neuen Darstellung der Logik mit steter Rücksicht auf deren bisherige Bearbeiter, 4 vols., Sulzbach.

Brentano, Franz. 1889. "Vom Ursprung sittlicher Erkenntnis" (Lecture), chap. 1 of Brentano, Vom Ursprung sittlicher Erkenntnis. Leipzig: Duncker and Humblot, 3rd rev. ed. Leipzig: Meiner, 1934; Eng. trans. The Origin of our Knowledge of Right and Wrong, by R. M. Chisholm and E. H. Schneewind. London: Routledge and Kegan Paul, 1969.

1924/25. Psychologie vom empirischen Standpunkt, 2nd ed., 2 vols., with introduction and notes by O. Kraus; Eng. trans. Psychology from an Empirical Standpoint, by L. L. McAlister, et al. London: Routledge and Kegan Paul, 1973.

Burkhardt, Arim. 1986. Soziale Akte, Sprechakte und Textillokutionen. A. Reinachs Rechtsphilosophie, und die moderne Linguistik. Tubingen: Niemeyer.

Coreth, E. 1973. "Frage" in Handbuch philosophischer Grundbegriffe, vol. 1. Munich: Kösel, 485-93. 
Delius, Harald. 1982. Self Awareness. A Semantical Inquiry. Munich: C. H. Beck.

Destutt de Tracy, Antoine L. C. 1803. Elémens d'idéologie, Part 2, Grammaire. Paris: Courcier.

Erdmann, Benno. 1907. Logik, Logische Elementarlehre, 2nd ed. Halle: Niemeyer.

Fales, Walter. 1943/44. "Phenomenology of Questions," Philosophy and Phenomenological Research, 4, 60-75.

Geiger, Moritz. 1911. "Das Bewußtsein von Gefühlen," in Pfänder, ed., 125-62.

— 1933. "Alexander Pfänders methodische Stellung," in E. Heller and F. Löw, eds., Neue Münchener Philosophische Abhandlungen (Pfänder Festschrift). Leipzig: Barth, 1-16.

Harrah, David. 1961. "A Logic of Questions and Answers," Philosophy of Science, 28, 40-46.

— 1969. "Erotetic Logistics," in K. Lambert, ed., The Logical Way of Doing Things. New Haven and London: Yale University Press, 3-21.

Hopper, Paul J. 1979. "Aspect and Foregrounding” in T. Givón, ed., Discourse and Syntax, Syntax and Semantics 12. New York: Academic Press, 213-60.

Husserl, Edmund, 1900/01. Logische Untersuchungen. Halle: Niemeyer, collected edition as Husserliana vol. XVII (ed. E. Holenstein) and vols. XIX/1, XIX/2 (ed. U. Panzer).The Hague: Niihoff, 1975/1984. Eng. trans, Logical Investigations, by J. N. Findlay. London: Routledge and Kegan Paul, 1970. (The translation has been amended where necessary.)

1913. Ideen zu einer reinen Phänomenologie und phänomenologischen Philosophie, I. Buch, Allgemeine Einführung in die Phänomenologie. Halle: Niemeyer, and as Husserliana III, 1 (ed. K. Schuhmann). The Hague: Nijhoff, 1976. 1968. Briefe an Roman Ingarden. The Hague: Niihoff.

Ingarden, Roman. 1925. "Essentiale Fragen," Jahrbuch für Philosophie und phänomenologische Forschung, 7, 125-304.

— 1931. Das literarische Kunstwerk. Eine Untersuchung aus dem Grenzgebiet der Ontologie, Logik und Literaturwissenschaft. Halle: Niemeyer; Eng. trans. by G. G. Grabowicz as The Literary Work of Art. Evanston: Northwestern University Press, 1973. 1964/65. Der Streit um die Existenz der Welt, in 2 volumes, the 2nd in 2 parts. Tübingen: Niemeyer.

Karttunen, Lauri. 1977. "Syntax and Semantics of Questions," Linguistics and Philosophy, 1, 3-44. 
Kreibig, Josef K. 1914. "Beiträge zur Psychologie und Logik der Frage," Archiv für die gesamte Psychologie, 33, 152-212.

Lipps, Theodor. 1905. "Die Wege der Psychologie," Atti del V Congresso Internazionale di Psicologia, S. de Sanctis, ed. Rome: Forzani, 57-70.

Longacre, Robert and Levinson, Stephen. 1978. "Field Analysis of Discourse," in W. U. Dressler, ed., Current Trends in Linguistics. Berlin/New York: Walter de Gruyter, 103-22.

Lotze, Hermann. 1912. Logik. Drei Bucher vom Denken, vom Untersuchen und vom Erkennen, G. Misch, ed. Leipzig: Meiner.

Löw, Friedrich. 1928. "Logik der Frage," Archiv für die gesamte Psychologie, 66, 357-436.

Lyons, John. 1977. Semantics, vol. 2. Cambridge: Cambridge University Press.

Marty, Anton. 1908. Untersuchungen zur Grundlegung der allgemeinen Grammatik und Sprachphilosophie. Halle: Niemeyer, repr. Hildesheim and New York: Olms, 1976.

Meinong, Alexius, 1910. Über Annahmen, 2nd ed. Leipzig: Barth, repr. in Meinong, Gesamtausgabe, vol. IV. Graz: Akademische Druckund Verlagsanstalt, 1977; Eng. trans. On Assumptions by J. M. Heanue. Berkeley/Los Angeles/London: University of California Press, 1983.

Mulligan, Kevin, ed. 1987. Speech Act and Sachverhalt. Reinach and the Foundations of Realist Phenomenology. Dordrecht/Boston/ Lancaster: Nijhoff.

Mulligan, Kevin and Smith, Barry. 1986. "A Relational Theory of the Act," Topoi, 5/2, 115-30.

Nehring, Alfons. 1963. Sprachzeichen und Sprechakt. Heidelberg: C. F. Winter.

Paul, Hermann. 1920. Prinzipien der Sprachgeschichte, 5th ed. Halle: Niemeyer.

Pfänder, Alexander. 1909. "Imperativenlehre," first published in Spiegelberg and Avé-Lallemant, eds. 1982, 295-324.

— 1921. "Logik," Jahrbuch für Philosophie und phänomenologische Forschung, 4, 139-494, and as Separatum. Halle: Niemeyer, 1921 (3rd. ed., Tübingen: Niemeyer, 1963).

Pöltner, Günther. 1972. Zu einer Phänomenologie des Fragens. Freiburg/Munich: Alber.

Rausch, Edwin. 1977. "Betonungsproblem und Variabilitäts-KonstanzVerhältnis," Archiv für Psychologie, 123, 235-43. 
Reinach, Adolf. 1911. "Zur Theorie des negativen Urteils," in Pfänder, ed., Münchener Philosophische Abhandlungen (Festschrift for Theodor Lipps), 1911, 196-254, repr. in Reinach 1921, 56-102; Eng. trans. "On the Theory of the Negative Judgment," in Smith, ed., 315-77.

— 1912/13. "Die Überlegung," Zeitschrift für Philosophie und philosophische Kritik, part I, 148, 181-96, part II, 149, 30-58, repr. in Reinach 1921, 121-65.

— 1913. "Die apriorischen Grundlagen des bürgerlichen Rechts," Jahrbuch für Philosophie und phänomenologishe Forscbung, I/2, 685-847, and as Separatum, 1913 and 1922; repr. in Reinach 1921, 166-350; Eng. trans., "The Apriori Foundations of the Civil Law," by. J. F. Crosby, Aletheia, 3, 1-142.

1921. Gesammelte Schriften, herausgegeben von seinen Schülern (mainly by F. Stein), with an Introduction by H. Conrad-Martius. Halle: Niemeyer. New critical edition, ed. K. Schuhmann and B. Smith, Munich: Philosophia, forthcoming.

Rickert, Heinrich. 1904. Der Gegenstand der Erkenntnis. Einführung in die Transzendentalphilosophie, 2nd revised ed. Tübingen: Mohr (Siebeck).

Rombach, Heinrich. 1952. "Über Ursprung und Wesen der Frage," Symposion (Jahrbuch für philosophie), 3, 135-236.

Rubin, Edgar 1921. Visuell wahrgenommene Figuren. Copenhagen: Glydendalske Bokhandel.

Schuhmann, Karl. 1977. Husserl-Chronik. Denk- und Lebensweg Edmund Husserls. The Hague: Nijhoff.

— 1985. "Structuring the Phenomenological Field: Reflections on a Daubert Manuscript," in W. S. Hamrick, ed., Phenomenology in Theory and Practice. Dordrecht/Boston/Lancaster: Niihoff.

— 1987. "Johannes Dauberts Kritik der 'Theorie des negativen Urteils' von Adolf Reinach," in Mulligan, ed.

Schuhmann, Karl and Smith, Barry. 1985. "Against Idealism: Johannes Daubert vs. Husserl's Ideas I," Review of Metaphysics, 38, 763-93.

— 1987. "Adolf Reinach: An Intellectual Biography," in Mulligan, ed.

Searle, John R. 1969. Speech Acts. An Essay in the Philosophy of Language. Cambridge: Cambridge University Press.

Selz, Otto. 1913. Über die Gesetze des geordneten Denkverlaufs, I, Stuttgart: Spemann.

Sigwart, Christoph. 1904. Logik, I, Die Lehre vom Urteil, vom Begriff und vom Schluss, 3rd ed. Tübingen: J. C. B. Mohr. 
Smid, Reinhold N. 1985. "An Early Interpretation of Husserl's Phenomenology: Johannes Daubert and the Logical Investigations," Husserl Studies, 2, 267-90.

Smith, Barry. 1978. "An Essay in Formal Ontology," Grazer Philosophische Studien, 6, 39-62.

— 1985. "Materials Towards a History of Speech Act Theory," manuscript forthcoming in A. Eschbach, ed., Karl Bühler's Theory of Language. Amsterdam: Benjamins.

— 1985a. "Ten Conditions of a Theory of Speech Acts," Theoretical Linguistics, 11, 311-30.

_ 1986. "Edmund Husserl and the Ontology of Language," in D. Buzzeti and M. Feriani, eds., Universal Grammar, Speculative Grammar, Philosophical Analysis. Amsterdam: J. Benjamins, 143-65.

- 1987. "On the Cognition of States of Affairs," in K. Mulligan, ed., Speech Act and Sachverhalt.

Smith, Barry, ed. 1982 Parts and Moments. Studies in Logic and Formal Ontology. Munich: Philosophia.

Spiegelberg, Herbert. 1982. The Phenomenological Movement, 3rd ed. The Hague/Boston/London: Nijhoff.

Spiegelberg, Herbert and Avé-Lallemant, Eberhard, eds. 1982. PfänderStudien. The Hague: Nijhoff.

Stahl, Gerold. 1969. "The Effectivity of Questions," Noûs, 3, 211-18.

Stern, Günther (Günther Anders). 1924. Die Rolle der Situationskategorie bei den "Logischen Sätzen." Dissertation, Freiburg i. Br.

Struyker Boudier, C. E. M. 1979. "De metafysiese betekenis van de vraag," Tijdschrift voor Filosofie, 41, 447-84.

Tumlirz, Otto. 1919. Das Wesen der Frage. Beiträge zu ihrer Psychologie, Gegenstandstheorie, und Pädagogik. Prague: A. Haase.

Wallace, Stephen. 1982. "Figure and Ground: The Interrelationships of Linguistic Categories," in P. Hopper, ed., Tense-Aspect: Between Semantics and Pragmatics. Amsterdam/Philadelphia: John Benjamins, 200-23.

Wunderlich, Dieter. 1976. Studien zur Sprechakttheorie. Frankfurt a.M.: Suhrkamp. 